\title{
UNAUTHORIZED MINING IN RIVERS: HYDRAULIC HAZARD AND ITALIAN LAWS
}

\author{
P. FILIPPINI ${ }^{1}$, S. MAMBRETTI ${ }^{2}$ \& M. PETRELLA ${ }^{3}$ \\ ${ }^{1}$ Public Prosecutor's Office, Court of Milano, Italy. ${ }^{2}$ DIIAR, Politecnico di Milano, Italy. \\ ${ }^{3}$ Provincial Local Police, Environmental Section, Lodi, Italy.
}

\begin{abstract}
Unauthorized mining is regarded as a minor crime because river areas are commonly perceived as plentiful in building materials such as sand and gravel. The paper roughly estimates the quantities which may be removed every year and shows the consequences of immoderate mining both in theoretical terms and by means of case studies. Estimated self-recovery times may be in the order of hundreds of years. Techniques to combat these illegal activities are presented, together with the new instruments used by police forces specialized in environmental crimes and the new cooperation standards established experimentally in the River Po catchment area. Finally, the paper discusses the modifications scheduled for the criminal code, presenting the most important changes. Moreover, because the scheduled adjustments have not yet been approved, the paper analyzes the current section of the penal code which punishes these crimes.

Keywords: environmental crimes, flood hazard, investigations, mining, penal code.
\end{abstract}

\section{INTRODUCTION}

Firms working in civil construction are in constant search of building materials, especially gravel and sand. When these materials are obtained from rivers, they are considered to be of good quality, and moreover as already "washed" by the water of the river itself.

Authorization to mine in rivers is therefore a benefit for the companies operating in this sector. Their profit obviously increases if the mining is unauthorized or only partially authorized, given the extra income deriving from non-payment of the correct amount of taxes and non-declaration of the sale of the materials.

Although these fiscal aspects are very important, they are not discussed in the paper, which is concerned with environmental damage and particularly with the increase in hydraulic hazard. The paper also illustrates the means used by these companies to obtain at least partial authorization, or the justifications put forward for locating their plants close to rivers.

In order to verify the lawfulness of the mining work carried out by these companies, procedures for investigation and detection of illegal activities have been developed. These too are covered by the paper.

Finally, if committing these offences is proven, Italian law comprise rules on the punishment of offenders. These rules are about to change: the paper highlights the problems concerning the current laws, together with the improvements expected from the new regulations.

In conclusion, the paper stresses that environmental offences of this kind are frequently underestimated, also by public opinion, although they are of paramount importance for land conservation and public safety, so that efficient control, supported by appropriate laws, is essential.

\section{DIMENSIONS OF THE PROBLEM}

Obviously, it is not possible to estimate the problem in Italy with precision. However, it is possible to cite two exemplary cases in order to give an idea of the importance of the phenomenon. 
The first case concerns the River Po, and a reach of it which extends for approximately $30 \mathrm{~km}$. It has been estimated that more than 7 million cubic meters of material have been removed from this reach in less than 8 years. Because this is a part of the river where sediments tend to deposit, this volume should be considered underestimated; moreover, for the same reason, the lack of material should be ascribed to human activities.

The problem of unauthorized mining can also be assessed by comparing the abovementioned volume with the one authorized, for the same reach, by the Interregional Agency for the Po River (i.e. the Authority which issues authorizations for mining activities on the Po and its tributaries), which was equal to $3,695,000 \mathrm{~m}^{3}$ for the period 1982-2002 [1].

Smaller rivers may have larger problems. The River Vomano, in the centre of Italy, had been mined for about 10 years by the mid-1960s, with the removal of a volume of building material approximately equal to 3.2 million cubic meters (and probably more, [2]). The mining was forbidden in the early 1980s, but major erosion phenomena had already begun: bridges and structures collapsed, and the problem is still far from being solved (Fig. 1).

As said, it is not possible to estimate the problem accurately in Italy. However, it is possible to compute the need for building materials: constructing $1 \mathrm{~km}$ of highway requires $62,000 \mathrm{~m}^{3}$ of sand and gravel; $1 \mathrm{~km}$ of viaduct requires $30,000 \mathrm{~m}^{3}$; and so on. It is likely that the companies specialized in working and selling these materials exceed the limits stated by their authorizations.

In Italy the market for cement and concrete is very large: every year each citizen needs, on average, $800 \mathrm{~kg}$ of cement and $10,000 \mathrm{~kg}$ of sand and gravel. The demand is lower in other countries, because constructions are more limited and the recycling of materials from demolitions is a frequent practice.

This high demand yields large revenues: from 1970 to 1990 the price of building material doubled with respect to the cost of living, and more than doubled if stock prices are considered [3]. Moreover, regional taxes are very low. In the region of Emilia Romagna they amount

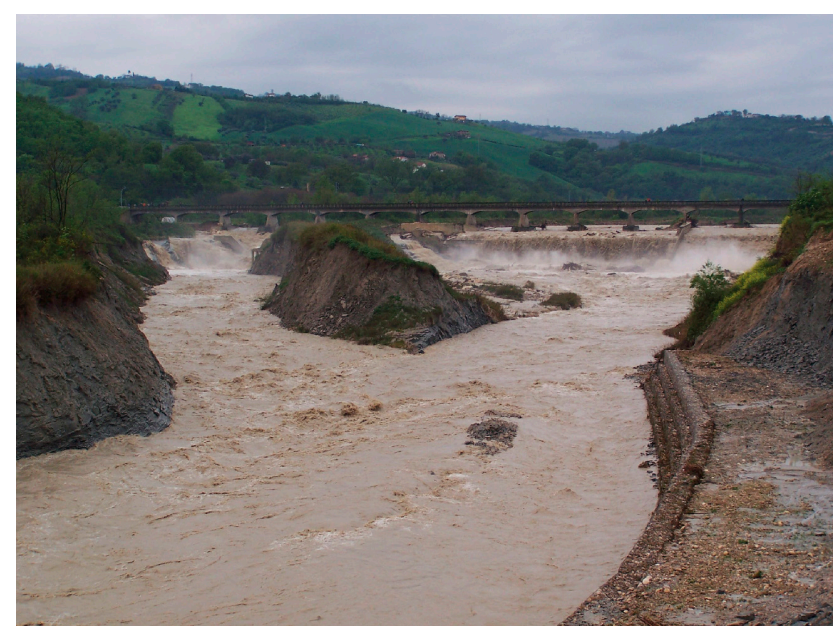

Figure 1: Erosion in a river in the Centre of Italy. Downstream from the bridge a checkdam has been built to prevent the bridge's collapse. However, over the years, the checkdam itself has had several problems. The origin of the erosion is believed to be excessive mining. 
to $4 € / \mathrm{m}^{3}$ to mine in the River Po (which is the highest value in Italy), and completely absent in some southern regions like Puglia, Basilicata, Sicily and Sardinia [4].

Taking the River Po again as an example, Legambiente [4] reports that in 1993 in the reach between Piacenza and the sea, at least 60 worksites were operating for an average daily potential output of $1,500 \mathrm{~m}^{3}$. On the basis of 200 working days per year, the total amount is equal to 18 million cubic meters, which would reduce the river's thalweg by about $15 \mathrm{~cm}$ per year.

Estimates on business volume again calculated by Legambiente show that an equipped boat can make 3-5 trips per day, loading about $400 \mathrm{~m}^{3}$ per trip, which is a volume per day ranging between 1,200 and 2,000 $\mathrm{m}^{3}$. Because the price of sand is between 20 and $25 € / \mathrm{m}^{3}$ and estimating 150 working days per year, the total amount is 5 million euros per year. If the mining were completely unauthorized, the business volume would be very high, and obtained with few instruments and quite simply.

\section{APPLICATIONS FOR AUTHORIZATION}

Equipped boats can be easily detected by river surveillance. Hence, as said, even operators intending to carry out illegal quarrying must have a reason for owning and positioning their boats without being immediately intercepted.

Applications for authorization can be very different, and sometimes imaginative. In the experience of the authors, the following authorizations are the most common:

1. for agricultural improvements;

2. for docking;

3. to deepen the river for navigation;

4. to construct fish tanks.

\subsection{Authorization for agricultural improvements}

During major atmospheric events, cultivated land close to rivers may be flooded; in these cases, the sand deposited makes such land difficult to cultivate. As a consequence, it is sometimes permitted to replace the first decimetres of terrain, which is sand, with terrain of better quality. The work is usually performed with simple machinery and in a short time, because levees may be flooded with relatively small return periods. In other words, it is necessary to carry out the minimum amount of work (at the minimum cost), and rapidly, in order to use the land before the next flood.

Excavations like those shown in Figure 2 (the photograph was taken during investigations) are not justifiable as agricultural improvements. The hazard here is also increased owing to the complete lack of vegetation, and because the material is removed rather frequently.

\subsection{Authorization for docking}

When working on levees, the availability of a river boat to transport material may be very useful. Although these boats are designed for navigation where the water depth is low, close to the bank of the river the depth may be so low that it is impossible for the boat to approach. Consequently, authorization to mine the river may be requested. This authorization is given on the condition that the material is replaced in the river, downstream from the dock, thus preventing depletion of the river. Rather obviously, after this first phase, companies usually ask to keep the material excavated. 
The problem is that the river is in dynamic equilibrium. If a hole is made in the bed of a river, it is rapidly filled because of the arrival of material from upstream. Hence, to maintain a hole of given dimensions, it is necessary to constantly remove material. The longer it is intended to maintain the hole, the larger is the volume of material that must be removed.

Not only does this phenomenon occurs naturally but it is also aggravated in locations where the river tends to deposit, which, incidentally, are the places that operators prefer when they want to collect good quality material.

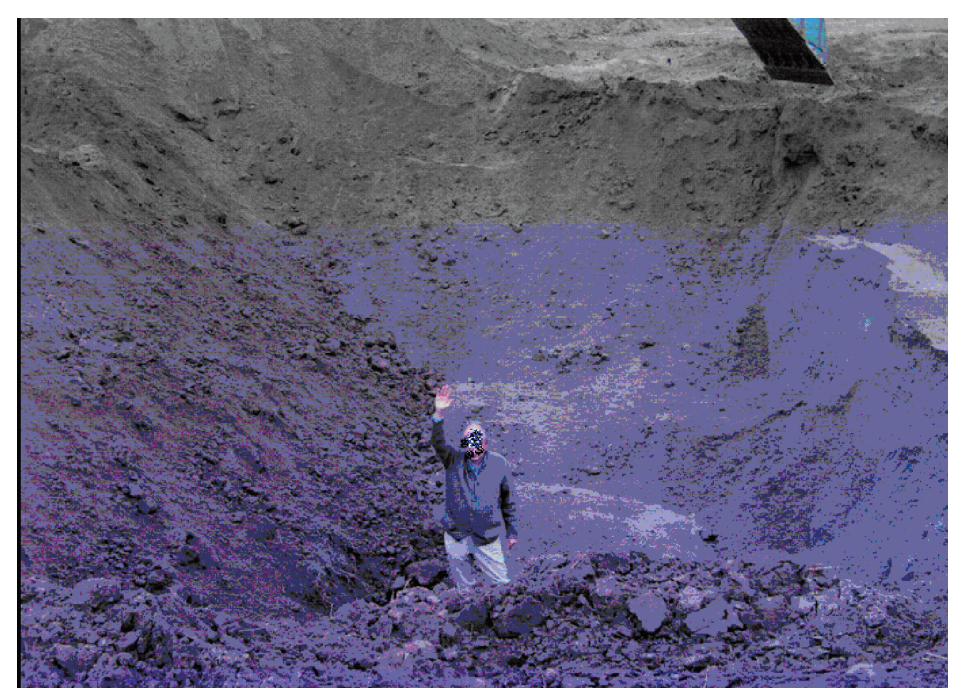

Figure 2: A large excavation in terrain supposed to be worked on for agricultural improvements.

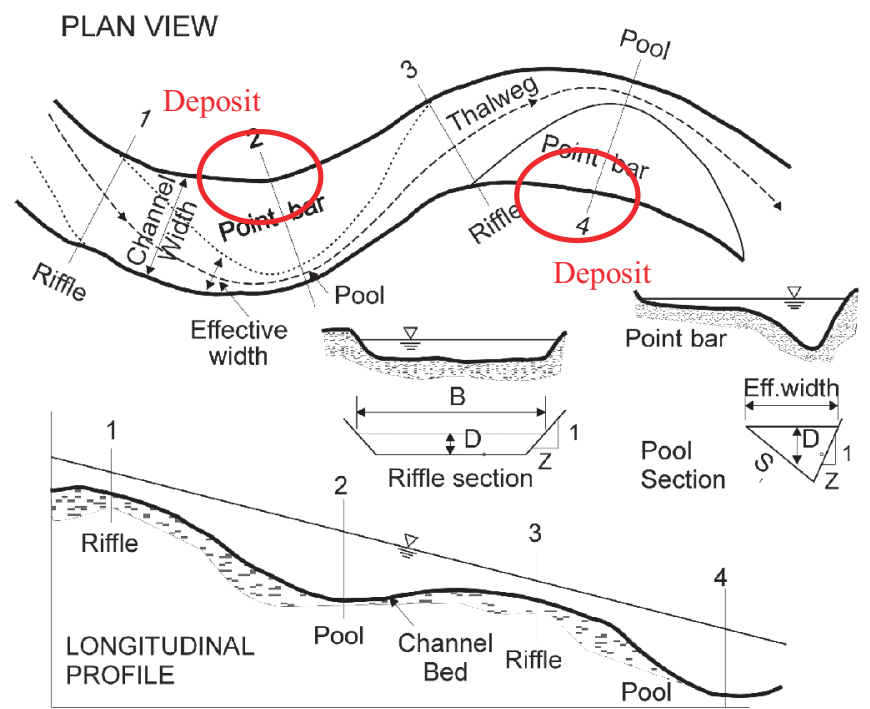

Figure 3: Trend of thalweg in a meandering river [5]. 


\subsection{Deepening of the river for navigation}

This case is very similar to the previous one. The reason for the excavation request is that the water depth is too low and material must be removed with boats. The use of boats is in some cases better than the use of trucks, which may damage the embankments and take too long to reach the opposite edge. To this end, excavations are made in order to build underwater paths which enable connection between two points of the same river.

In this case, too, the authorization should be given on condition that the excavated material is replaced in the river. Usually, as mentioned above, operators then ask for permission to keep the material. Obviously, as the upcoming material falls into the hole, according to the mechanism shown in Figure 4, there will be a constant need to continue the excavation.

\subsection{Construction of fish tanks}

This request, apparently harmless, is actually one of the most insidious. First of all, there are negative effects on the environment, which will be described in the following section. To be noted is that the largest income derives, not from the pisciculture, but from the excavation undertaken to construct the tank. It may happen that the excavation goes deeper than authorized. Obviously, checking the level of the excavation from a boat is easy, rapid and cheap. As a consequence, a fraudulent operator must fill a hole which can be very large. The most economical way to do this is to use material from demolitions, which will yield further revenue

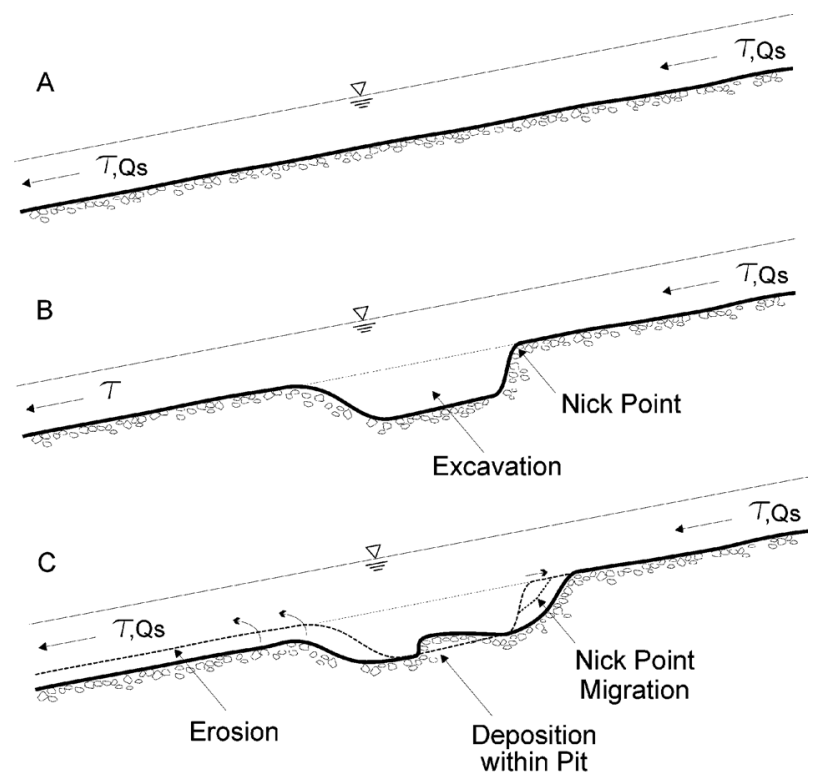

Figure 4: Excavation in a river. (a) Shows the initial condition, before the excavation, when the discharge of sediments $Q_{s}$ and the shear stress $\tau$ are continuous in the reach. (b) The excavation creates an accumulation point which works as a "trap" for the sediments, obstructing the solid transport. However, downstream, the river still has transport capacity, but a reduced discharge is arriving. (c) The hole expands both upstream and downstream, also causing the river bed to lower [6]. 
(because the fees for dumping are quite high) and make the investigation more complex and costly (because it is necessary to take samples to verify the nature of the bottom).

\section{RIVER MINING AND HYDRAULIC RISKS}

Common sense suggests that, concerning environmental hazards, and hydraulic hazard in particular, the same operation may increase the risk in some parts of the reach and decrease it in others. In fact, a river system is interrelated and an action taken in some location may affect the river far downstream and upstream. For instance, increasing the elevation of an embankment reduces the risk of flooding in nearby land, but it brings the flood wave downstream with little lamination (and maybe more rapidly, because of the reduced roughness of the rehabilitated reach) and therefore increases hydraulic hazard for the land situated downstream.

However, it is well known that when river mining is not determined by hydraulic needs (i.e. the need to remove from the river bed the obstacles that can obstruct the regular flow), it raises problems without any reward. The erosion phenomena created by mining then propagate both downstream and upstream, even for several kilometres [6-8].

The following problems have been widely observed:

- erosion of both longitudinal and transversal hydraulic structures, among them embankments [5,9-11];

- increased vulnerability of structures with foundations in the river bed, among them bridges [12,13];

- change in the natural slopes of rivers due to erosion processes [14];

- degradation of the fluvial ecosystem, loss of humid zones, and consequent modification of the typical marshes which host a great number of animals; moreover, reduction in stocks of fish, biomasses and invertebrates [15,16];

- mining on levees is equally dangerous from the biological point of view because of the formation of deposits of polluted water, where heavy metals concentrate and damage the biological habitat [16-18];

- groundwater levels decrease close to rivers, with a tendency to aridification of the surrounding land [19];

- difficulties for the hydraulic structures which collect or divert water (for hydropower plants, water supply, irrigation, etc.).

Again, it is not possible here to illustrate in detail all the problems mentioned. Hence, as previously done, only few examples are described and discussed.

Figure 5 reports the case of an increase in the vulnerability of a bridge-pipe due to the amplification of dramatic erosion phenomena, whose origin some authors (e.g. [2]) attribute to excessive mining. In the case shown in the picture, [2] reports that in the years between 1983 and 1988 the erosion caused a lowering of the river bed by about $6 \mathrm{~m}$, which is on average $1.2 \mathrm{~m}$ /year. Because of the progressive uncovering of the foundations, in 1988 new works were undertaken, increasing the length of the pile foundation by $20 \mathrm{~m}$. In December 1994 the new foundation was uncovered to $4.5 \mathrm{~m}$ and in 2004 to $8 \mathrm{~m}$ (Fig. 5): in that decade, therefore, the velocity of erosion was about $35-40 \mathrm{~cm} /$ year.

Rovira et al. [19] report the case of the River Tordera in the North-East of Spain, where over 15 years of intense mining lowered the river bed by about $1.5 \mathrm{~m}$. The damage mostly caused by mining in this period is shown in Table 1 . Among the main forms of damage 


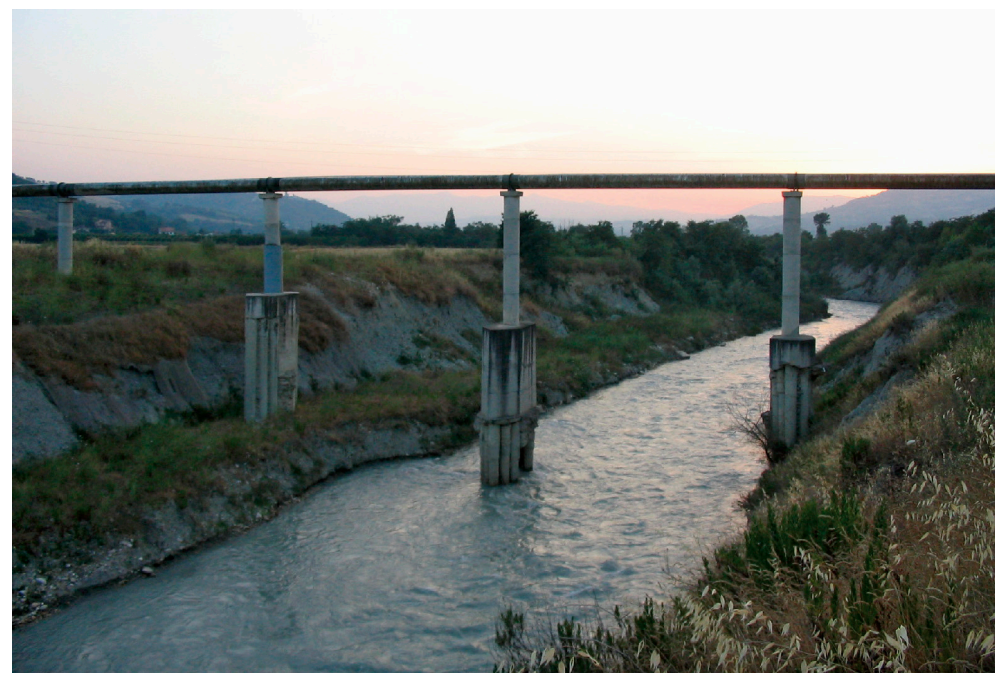

Figure 5: In 2004 the pile foundation was uncovered by $8 \mathrm{~m}$.

Table 1: Effect of the flood waves on the River Tordera when mining was allowed (after Rovira et al. [19]).

\begin{tabular}{ll}
\hline Infrastructure & Flood (year) \\
\hline Industry of aggregates damaged/loss & $1962,1969,1971$ \\
Railway damaged & $1962,1965,1971$ \\
Station bridge damaged & $1962,1963,1965,1969$ \\
Road BV 5122 damaged & $1962,1965,1969,1971$ \\
Park damaged & $1962,1963,1965,1971$ \\
Tordera bridge damaged & $1962,1963,1965,1969$ \\
Road to Madrid/France damaged & 1962,1971 \\
Textile industry flooded & $1962,1963,1969,1971$ \\
Field with yield loss & 1962 \\
Road to Malgrat/Blanes flooded & 1962 \\
Industry flooded & 1962 \\
Railway bridge damaged & 1962 \\
Old bridge Malgrat/Blanes damaged & 1962,1971 \\
Artificial levee damaged & $1962,1963,1965,1969,1971$ \\
Artificial levees damaged in 19 sections & 1982 \\
Campground flooded & 1994 \\
\hline
\end{tabular}

reported, to be highlighted are the cutting of a meander in 1987, the collapse of a number of structures, the flooding of the village of Tordera in 1971, the collapse of embankments for more than $300 \mathrm{~m}$ in 1982, and the erosion of 3-4 ha of agricultural land. Moreover, the damage related to the ecosystem and the groundwater is not reported in Table 1. 
The Spanish authorities have drawn up many projects for remedial action, but without significant results. Mining was completely forbidden in 1987 and thereafter the river bed began to rise again, although the time necessary for complete recovery has been estimated at around 420 years.

As can be seen, the problems due to "simple" river mining are very complex and diverse. The fluvial system, in fact, seeks to find an equilibrium; and when some factor, either natural or anthropic, perturbs it, the system tends to find a new equilibrium in its new status. In order to prevent activities which change the natural equilibrated system in an uncontrolled way, it is necessary that all the activities not be undertaken locally; or, in other words, that local actions are included in a comprehensive framework.

To check, to some extent, literature data, some simulations have been carried out on the river Po, on a reach 31,648 km long, where excavations have been found. Only few results can be reported in the paper. The reach has been divided in 20 river sections and simulated with HEC-RAS in permanent flow, with a discharge equal to $1000 \mathrm{~m}^{3} / \mathrm{s}$. This value is to be considered related to a quite large event, but it has been already recorded in the year 2000. Some of the carried out results are reported in Table 2, showing in particular the velocities the flow can reach in the floodplains. These values, up to $1 \mathrm{~m} / \mathrm{s}$, show that if the land was covered by vegetation, terrain would be stable; unfortunately, the landscape looked as shown in Figure 6 and therefore the site seems to be much more critical and prone to erosion.

Another increase of risk has been proved checking the embankments stability. The changes in the river sections are briefly shown in Table 3, and the sliding surfaces computed for the

Table 2: Results from HEC - RAS simulations for a reach in the Po River.

\begin{tabular}{lcccccc}
\hline & $\begin{array}{c}\text { Vel Left } \\
{[\mathrm{m} / \mathrm{s}]}\end{array}$ & $\begin{array}{c}\text { Vel Right } \\
{[\mathrm{m} / \mathrm{s}]}\end{array}$ & $\begin{array}{c}\text { Vel Chnl } \\
{[\mathrm{m} / \mathrm{s}]}\end{array}$ & $\begin{array}{c}\text { Shear Chan } \\
{\left[\mathrm{N} / \mathrm{m}^{2}\right]}\end{array}$ & $\begin{array}{c}\text { Shear LOB } \\
{\left[\mathrm{N} / \mathrm{m}^{2}\right]}\end{array}$ & $\begin{array}{c}\text { Shear ROB } \\
{\left[\mathrm{N} / \mathrm{m}^{2}\right]}\end{array}$ \\
\hline Sec. 11 & 0.79 & 0.45 & 1.86 & 18.59 & 5.05 & 2.18 \\
Sec. 12 & 0.91 & 0.64 & 1.79 & 17.08 & 6.17 & 3.66 \\
Sec. 12A & 0.68 & 0.53 & 1.62 & 13.70 & 2.59 & 2.55 \\
Sec. 13 & 0.71 & 0.47 & 1.17 & 7.44 & 3.55 & 1.89 \\
Sec. 14 & 0.71 & 0.58 & 1.55 & 13.38 & 4.13 & 3.01 \\
Sec. 14A & 0.59 & 0.55 & 1.42 & 10.95 & 2.95 & 2.40 \\
Sec. 15 & 0.74 & 0.64 & 1.97 & 19.2 & 4.36 & 3.54 \\
Sec. 15A & 0.57 & 0.43 & 1.11 & 6.62 & 2.40 & 1.57 \\
Sec. 15B & 0.81 & 0.62 & 1.73 & 15.27 & 4.92 & 3.25 \\
Sec. 16 & 0.86 & 0.60 & 1.53 & 11.90 & 4.97 & 2.89 \\
Sec. 16A & 0.92 & 1.03 & 2.83 & 40.13 & 7.13 & 8.72 \\
Sec. 16B & 0.97 & 1.05 & 2.47 & 30.60 & 7.52 & 8.44 \\
Sec. 17 & 0.81 & 0.89 & 2.17 & 24.97 & 5.42 & 6.56 \\
Sec. 17BIS & 0.51 & 0.59 & 1.48 & 11.14 & 2.24 & 2.75 \\
Sec. 17A & 0.87 & 0.66 & 2.26 & 26.93 & 6.24 & 4.15 \\
Sec. 17B & 0.88 & 0.96 & 1.48 & 13.17 & 5.08 & 6.52 \\
Sec. 18 & 0.96 & 0.28 & 1.66 & 15.73 & 6.78 & 1.11 \\
Sec. 18A & 1.16 & 0.20 & 2.34 & 27.62 & 9.61 & 0.68 \\
Sec. 20 & 1.66 & 0.65 & 3.77 & 76.63 & 18.72 & 5.53 \\
\hline
\end{tabular}




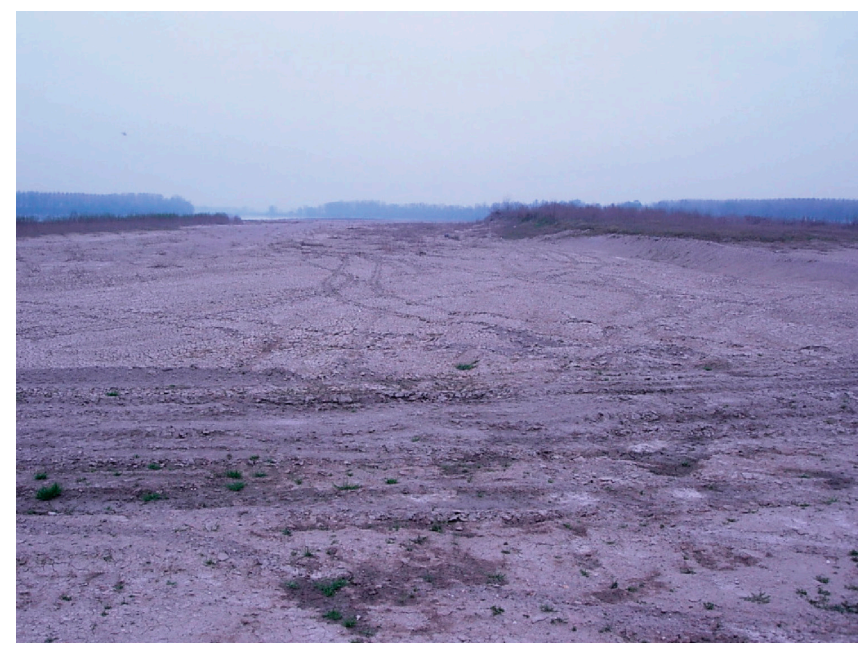

Figure 6: Po river floodplains, where investigations have been performed.

Table 3: Topographical results on the river sections.

\begin{tabular}{lcccc}
\hline & $\begin{array}{c}\text { Progressive } \\
\text { distance }[\mathrm{m}]\end{array}$ & $\begin{array}{c}\text { Differences on } \\
\text { section areas }\left[\mathrm{m}^{2}\right]\end{array}$ & $\begin{array}{c}\text { Section width } \\
{[\mathrm{m}]}\end{array}$ & $\Delta H[\mathrm{~m}]$ \\
\hline Sec. 11 & 299279 & $-530,6$ & 392,11 & $-1,35$ \\
Sec. 12 & 301449 & $-319,8$ & 582,38 & $-0,55$ \\
Sec. 12A & 303092 & $-84,3$ & 601,80 & $-0,14$ \\
Sec. 13 & 305528 & $+76,7$ & 745,85 & $+0,10$ \\
Sec. 14 & 307532 & $-296,1$ & 796,95 & $-0,37$ \\
Sec. 14A & 308598 & $-411,6$ & 781,42 & $-0,53$ \\
Sec. 15 & 310711 & $-229,1$ & 288,20 & $-0,79$ \\
Sec. 15A & 312364 & $+872,90$ & 712,94 & $+1,22$ \\
Sec. 15B & 314511 & $-402,5$ & 391,59 & $-1,03$ \\
Sec. 16 & 314992 & $-569,6$ & 480,29 & $-1,19$ \\
Sec. 16A & 316172 & $-213,3$ & 274,93 & $-0,78$ \\
Sec. 16B & 317180 & $-476,4$ & 316,83 & $-1,50$ \\
Sec. 17 & 319395 & $-30,21$ & 534,21 & $-0,06$ \\
Sec. 17BIS & 320311 & $-798,01$ & 619,75 & $-1,29$ \\
Sec. 17A & 323346 & $-255,66$ & 356,62 & $-0,72$ \\
Sec. 17B & 325093 & $-118,95$ & 619,75 & $-0,19$ \\
Sec. 18 & 325986 & $-942,62$ & 649,76 & $-1,45$ \\
Sec. 18A & 328157 & $+201,85$ & 280,98 & $+0,72$ \\
Sec. 20 & 328321 & -272.40 & 502.35 & -0.54 \\
Sec. 20A & 330927 & $-200,94$ & 392,32 & $-0,51$ \\
\hline
\end{tabular}

The three sections where deposition has been recorded are shown in italics. However, the whole reach of the river should be subject of deposition, but erosion has been recorded in the majority of the river sections. 

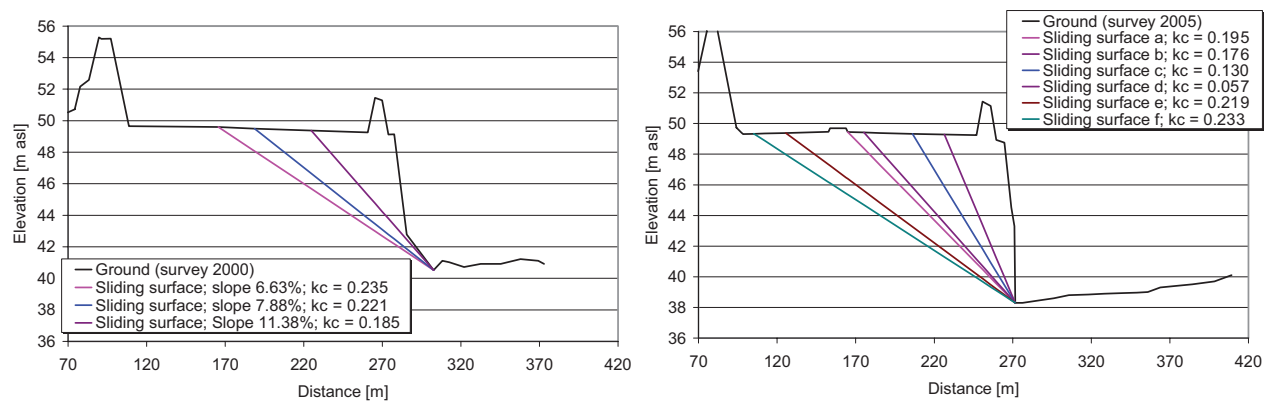

Figure 7: Modification of the river section through the years. In five years the stability of the embankment of the river sections has generally decreased (in figure: section 16B).

embankments as surveyed in 2000 and 2005 are reported in Figure 7, for the river section 16B. In the figure, the coefficient $k_{c}$ is the coefficient of horizontal acceleration: smaller coefficients imply greater instability. As can be seen, the embankment in 2005 is much steeper and therefore more instable, i.e. the risk of collapse is higher.

With regard to the bridge on the Po River, it has actually collapsed in 2009 , but the reasons of the collapse have still to be established by the Court and the different theories of the Experts of the parties are still confidential.

\section{INVESTIGATION ACTIVITIES}

In Italy, the law on mining (either in quarries or rivers) assigns control to the local authorities (Regions, Provinces and Municipalities) and to the river authorities (the largest of which in the North of Italy is that of the Po River, AIPO). In Lombardy, regional laws have partly delegated the issuing of authorizations to the Provinces, so that the Municipalities are responsible for control. As to rivers, authorizations are issued by regional local offices, on technical advice by AIPO.

\subsection{Forces on the ground}

Is it obvious that this control structure is entirely inappropriate, in particular with regard to controls on river mining and agricultural improvement works to be carried out in levee areas: most of the towns on the edge of the Po or Adda Rivers, in fact, have fewer than 1000 inhabitants. They often do not have a local police force, and a technician is present only one or two days a week. AIPO has reduced its personnel and they often do not have boats or off-road vehicles with which to reach the places to be inspected. Regional local offices also have reduced their personnel and, moreover, according to the law, they do not have effective powers.

Although the Corpo Forestale dello Stato (a police force specialized in defence of the environmental heritage) has performed a good number of qualified actions, it suffers from a chronic shortage of funds, means and personnel.

Finally, the Provincial Police belongs to the Provinces and operate especially to control hunters but, in general, to control the local territory. Moreover, they have the same powers as the other police forces. In fact, the Provincial Police, also because of increasing regional funds and legislation, have highly professional human resources and appropriate means with which to control the land, although they suffer from a lack of personnel. For instance, the 
Lodi Provincial Police has 12 off-road vehicles and two boats to control river areas. It can also use a regional helicopter and is acquiring off-road motorbikes to reach locations inaccessible by road. Similar situations are found in the North of Italy, while in the rest of the country police forces are closely dependent on the individual Province.

\subsection{Methods of investigation}

Investigations are usually launched following reports (often anonymous) given by neighbours, competitors, anglers, and environmental activists, and following regional controls by police forces and their intuitions.

Whatever the reason for the investigation, the control methods used on the ground often depend on the type of country and the criminal organization concerned. Obviously, land without vegetation and with large open spaces makes direct control very difficult, while if the land is hilly or wooded direct checks can be made with binoculars and cameras.

However, experience shows that indirect controls with cameras, telephone or radio intercepts are always better than direct ones. Radios are very often used on the boats, where they must be installed for safety reasons, and they are the best means for "vigilantes" to maintain surveillance on the activities of illegal river miners. In fact, the latter have developed security systems in order to evade controls. One of them is the use of "sentries" which patrol the reach upstream and downstream from the boats in action (sometimes with smaller and faster boats) and communicate by radio or mobile phone when they see suspected inspectors approaching.

For these reasons, phone intercepts are the main and most efficient way to carry out investigations. In fact, although the "danger" of using the telephone is well-known, malefactors persist with it, often using metaphors or slang. But the messages collected, enable assessment of the entire criminal structure and constitute proof which can be used at trial.

Unfortunately, this useful instrument is at risk owing to the strong restrictions that the present government intends to introduce, allegedly to protect privacy, for crimes that do not exceed a given level of punishment. Among these are all environmental crimes, so that future investigations in this area will be impeded.

\subsection{Coordination}

What is lacking is efficient coordination among the forces operating on the same territory, especially along regional and provincial boundaries, as well as a common strategy in the planning of investigation and control activities.

In fact, the above-described means have scant efficiency if there is a lack of communication among authorities. For instance, it takes months to determine whether or not a boat working on the river is authorized to do so.

To this end, and at the time of writing, on proposal by the Province of Lodi, a meeting has been held at the AIPO headquarters between all the Provincial Police Commanders responsible for controlling the Po and Adda rivers. The purpose was to draw up agreements among authorities to coordinate control activities on these rivers under the AIPO's supervision.

This project, the first of its kind in Italy, will be an attempt to prevent a phenomenon - the theft of building materials from river beds - which in recent years has caused great damage to the ecosystem and to embankment safety, and has yielded huge revenues for the companies involved. 
Repressive capacity has also increased. To this end, local prosecutor's offices are now training judges, and in some cases (for instance the Courts of Milano and Lodi) have formed specialized police units.

The traditional police forces (Carabinieri, Provincial Police, Corpo Forestale, Guardia di Finanza) have improved their investigative techniques (the use of cameras, telephone and radio intercepts). In particular, the Provincial Police of Lodi have developed new coordinated technological systems: echo-sounders installed on boats and integrated with the SCAUT system, which enables the comprehensive monitoring of river beds and camera recordings of the fluvial system, also obtaining the exact coordinates via GPS. These comprehensive documents are useful to public prosecutors and in trials, but also in administrative actions.

Nevertheless, in view of the huge equipped boats moored along the River Po, and officially authorized only for small-scale work, it is evident that the fight to protect Italy's rivers has only just begun. The proposed legislative changes to restrict wiretapping would make investigations much more difficult.

\section{ITALIAN LAW TODAY AND ITS FUTURE PROSPECTS}

"The Republic safeguards the natural landscape and the historical and artistic heritage of the Nation". This sentence is one of the fundamental principles enshrined in the Italian Constitution and it is the precept surmounting the hierarchy of legal sources for environmental protection. To be highlighted is that the Constitution assigns the duty of protection to the Republic, and not just to the State. It thereby allocates the duty to all territorial authorities, in accordance with section 114 of the Constitution, which states "The Republic is composed of the Municipalities, Provinces, Metropolitan areas, and the State". However, independently of the administrative powers for environmental protection devolved to the local authorities under so-called "administrative federalism", in order to coordinate and unify the rules on the matter, the Constitution vests primary legislative power in the State, which "has exclusive legislative powers in protection of the environment, the ecosystem and cultural heritage" (section 117 Cost). The main example of this ordering and integration of the matter is provided by approval of the comprehensive Law on the Environment (legislative decree no. 152, 3 April 2006) which deals with soil defence and anti-desertification measures, the protection of water against pollution, and hydraulic resources management.

With regard to the protection of rivers against events other than pollution, to be noted is that there are no specific regulations concerning the punishment of illegal behaviour which causes damage. Consequently, the protection of fluvial areas is assigned to "common" criminal law, which states the sanctions applicable. The lack of legal consistency on this point is also evidenced by the fact that there is no single police force specialized in investigating such damage, so that controls are undertaken by various law enforcement agencies: the environmental corps of Carabinieri belong to the Environment Ministry, the Corpo Forestale dello Stato to the Agriculture Ministry, while the Autorità di Bacino, the hydraulic, provincial, and mining police forces depend on local authorities, and AIPO is the interregional control agency in the Po river catchment area.

Moreover, it is necessary to identify the owner of the environment damaged. At the time of writing, the Council of Ministers has approved the first of the decrees on fiscal federalism, and in particular the one relative to state property. This rule transfers most of the state's natural assets to the local authorities, devolving hydraulic-maritime governance to the Regions. This radically changes the provisions of the Italian civil law code, whose section 822 declares that “... belonging to the State and part of government properties are ... rivers, 
streams, lakes and all water defined public by the Law". In this (new) way the injured party is no longer the State. The new law complicates matters further for trial procedure. In fact, should the local authority seek recompense before a court because a river has been illegally mined, its action would be obstructed by the provision on recompense for damages whereby the local authority does not constitute the injured party: in fact, article 311 of the abovementioned legislative decree 152/2006 states that "the Ministry of the Environment and Land Protection shall take action, also before the courts, to gain recompense for environmental damage", while section 318 of the same law abolishes both section 18 of the Law 349/1986 (which ruled that local authorities, besides the State, could take legal action for environmental damage) and section 9 sub-section 3 d.lgs. 267/2000 (which granted environmental associations substitutive power for local authorities should they fail to take legal action). Hence, the most recent and comprehensive Italian law on environmental protection - by contrast with the principles of subsidiarity and devolution inspiring the most innovative recent administrative reforms - empowers only a government office to take legal action in the field of environmental damage. However, the Supreme Court has been able redress matters by bringing legislation closer to the right of citizens to enjoy the environmental heritage without it being damaged by human actions. According to an interpretation oriented by the Italian Constitution, environmental damage has necessarily different repercussions on the land. As has been noted by the Constitutional Court (sentence no. 641/1987), the environment is an absolute and primary asset and its protection is essential for the quality of life, owing to the need for a natural habitat by individuals and the community. As a consequence of this conception of the environment and of a refunding right enshrined in the Italian Constitution (articles 2-3-9), the Constitutional Court established that the right to take legal action in the case of environmental damage pertains not only to the State (i.e. to the Environment Ministry) but also to the local authorities, i.e. the Municipalities, the Provinces, the Regions, which, as an effect of illegal activities have suffered economic losses, which can be recompensed (see Supreme Court of Appeal, sez. . III, 28th Oct. 2009 n. 755).

The above-mentioned considerations illustrate a complex framework, both prescriptive and administrative, tied to the essence of the asset to be protected because, as mentioned, land related environmental problems involve a number of interests, numerous injured parties, and several administrative actors. In addition there is a stratification of laws amended over time, as well as the European Community rules on environmental protection, so that the task of Supreme Court is to interpret and harmonize a constantly changing body of legislation.

But it is in the legal sanctions applicable to breaches of the rules on environmental protection that the Italian legal order most reveals the effect of the lack of harmonization and raises the main resistance to social demands for specific additions to the list of activities to be considered crimes and systematically integrated into the criminal code.

The determination of the Italian legislators to remedy the weakness in the system has been recently manifest on a number of occasions, when some draft laws have been presented for inclusion in the criminal code of new crimes against the environment. In 1999 the Council of Ministers, on advice by the Ecomafia Commission (the title indicates the interest of organized crime groups, notably the Mafia, in the environmental business), set up by the Ministry of the Environment. This Commission was charged with preparation for the projected 1996 European Council Convention on environmental crime and has drawn up a draft law with the aim of including new crimes in the criminal code. According to the report illustrating the proposed new law, the main reason for including these new crimes in the criminal code is the latter's better ability to understand the cultural orientation of citizens 
and to defend the heritage that is the foundation of the community. Moreover, the inclusion of these new offences in the criminal code shows that environmental offences are no longer mere misdemeanours but crimes, and therefore more serious and subject to longer prescriptive periods for prosecution. Despite the good intentions, however, the Commission's work halted, and the draft law was never approved by Parliament.

More recently the problem has been addressed by the government. On 24 April 2007 the Council of Ministers approved a draft law on environmental crimes which would introduce a new section, VI bis, in the criminal code. Among its most interesting innovations were the following provisions:

- Section 452 - quarter (Environmental disaster): Whosoever illegally releases into the environment substances or energy causing or contributing to cause an environmental disaster shall be punished with imprisonment for periods between three and ten years and a fine amounting to between 30,000 and 250,000 euros. Environmental disaster occurs when the offence is of a major extent, or the number of persons exposed to the risk is high or when public safety is compromised. The same punishment is applied if the offence determines a non-reversible change to the ecosystem.

- Section 452 - quinqies (Alteration of the natural heritage, flora and fauna): Besides the cases described in the sections 452-bis, 452-ter and 452-quarter, punishable with imprisonment for terms between one and three years and with a fine between 2,000 and 20,000 euros is whosoever illegally: a) steals or damages mineral or vegetable matter causing or contributing to cause the actual danger of enduring or major damage to flora or the natural heritage; b) steals animals or treats them so as to create the actual danger of enduring or major damage to fauna. In the case described in the first subsection, if the danger is realized, the penalty is increased by one third.

- Section 452 - sexies (Aggravating circumstances): In the cases described in the sections 452-bis, 452-ter, 452-quater and 452-quinquies, the penalty is increased by one third if the danger to the environment: a) is related to protected natural areas or goods subject to landscaped, environmental, historical, artistic, architectural, or archaeological constraints; b) derives from emissions of ionizing radiations.

Although approved by the government, this proposal has not yet been discussed in Parliament. Furthermore, during the sixteenth legislature, on 24 June 2009 a new proposal (no. 2533) was presented in the Chamber of Deputies which reiterated modification of the criminal code through inclusion of the above-mentioned new section VI bis.

The inertia of the Italian legislators has been partially overcome by the commitment to transpose the European Community laws, which pay particular attention to the environment: According to Directive 2008/99/EC, dated 19 November 2008, the member countries must comply, before 26 December 2010, with the obligation not only to provide for criminal penalties to counter intentional, or seriously negligent, human behaviour, which damages the environment, but also to determine precisely the liability, in the criminal trial, of the legal persons for whose benefit the environmental crimes have been committed. The European legislators thus impose on Italy the obligation to extend, before December 2010, the liabilities of companies that have benefited from breaches of environmental protection law by their administrators. Hence, the provisions of legislative decree no. 231 of 8 June 2001, relative to other crimes will be applied also to environmental offences, considering as liable, and therefore applying the penalty to, the legal persons that have profited from the criminal offence. In the 
case described here, if illegal mining in rivers is performed by a company operating in the building material markets, the legal person will be punished with fines, temporary or permanent interdiction, or confiscation of the company's property.

Whilst these are the proposals for changes to the criminal code, to return to the problem of illegal mining, we now illustrate the criminal sanctions that can be applied under the current "generic" laws.

1. Pluri-aggravated thief: The unauthorized theft of sand and gravel from a river or its neighbourhood is punished under the criminal code (section 624) because the perpetrator, for the purpose of profit, takes government property with economic value, removing it from the legitimate owner, in this case the Region, in which the river flows. This offence may have the aggravating circumstances listed in sections 61 and 625 of the criminal code and are frequently applied in the case of illegal mining. For instance, stolen gravel and sand are obviously subject to public availability; usually the crime is committed by more than three persons; in the case of large quantities, the crime causes serious economic damage; the perpetrators normally avail themselves of temporal or locational circumstances (at night, or during bad weather) impeding public defence. In all these cases the punishment ranges from between three and ten years of imprisonment, and a fine between 206 and 1549 euros, multiplied up to three times should the illegal act be repeated in time (section 81 of the criminal code).

2. Aggravated damage: Uncontrolled and indiscriminate mining induces the deterioration of areas not only because they cause the decrease of the materials removed but also because they alter the landscape. For this reason, in the absence of an authorization that allows a company to modify the landscape, the offence of criminal damage is inflicted (section 652 of the penal code) whereby whoever destroys or damages the property of other persons is punished. In this case, the damaged property belongs to the government, with the aggravating circumstance that the assets are subject to public availability. Consequently, section 635, subsection II, no. 3, of the criminal code provides for punishment with between 6 months and 3 years of imprisonment, and the public prosecutor may undertake investigations and begin trial proceedings without a formal accusation by a third person.

3. Destruction or damage of the natural heritage: The same offences may pertain to the less serious category of crimes reported in section 734 of the criminal code, which states that whoever, through construction, demolition or in any other manner destroys or damages the natural assets of the places under the Authority's protection, shall be punished with a fine between 1,032 and 6,197 euros. To be stressed in this regard is that rivers are part of the landscape assets listed in the Codice dei Beni Culturali e del Paesaggio (as declared in legislative decree 42/2004, section 142) and are therefore subject to special protection by the designated Authority, in this case the Region.

4. Works performed without authorization: Mining activities which modify the river and its embankments, without the necessary authorization, are sanctioned in accordance with section 181 of the Codice dei Beni Culturali e del Paesaggio (d.lgs 42/2004), which punishes whoever undertakes works of any type on landscape assets (which include rivers). The sanctions are imprisonment for up to 2 years and fines between 5,164 and 51,645 euros, in accordance with d.p.r. 380/2001, section 44, b. Most interesting is that the sentence also orders restoration of the place at the expense of the proven guilty party. 
5. Danger of flooding: A collateral effect of illegal mining in rivers is the most dangerous event for public health that consists in the flooding of adjacent areas. This effect, punishable under section 450 of the criminal code with imprisonment for up to 2 years, is obviously not intentional of the theft but is an indirect consequence, however predictable, of an illegal act committed to gain profit. The criminal code, in fact, among the crimes against the public health listed in part VI, specifically envisages in section 3 the offence of negligence, which causes risk relative to negligent actions or omissions which can cause a railway disaster, a flood, a shipwreck (section 450 penal code). Should the flood actually occur, those responsible are also punished under section 449 of the criminal code with imprisonment for terms between 1 and 5 years. Should the offence also cause injury or death, it is sanctioned with the punishments applying to injury or murder.

\section{CONCLUSIONS}

River mining is a highly profitable business which may induce not entirely honest operators to take advantage of their authorizations to obtain further benefits, and to acquire material which was not initially computed or allowed.

As sand and gravel are available from rivers in large volumes, it is believed that the mining of quantities larger than allowed does not cause damage to the state or to the environment.

This paper has tentatively estimated the phenomenon, even if this is very difficult in the Italian situation, and has provided a number of examples. Moreover, the conditions which can typically induce companies to take advantage of their mining authorizations (and the reasons why these authorizations are requested) have also been described.

The paper has subsequently described the risks that inaccurately evaluated mining may pose for the environment, especially with regard to hydraulic aspects, and it has referred to cases in the literature of ecosystem damage demonstrating that its effects may be dramatic.

Some methods of investigation have then been described, together with the new technical developments and actions undertaken, albeit experimentally, by local police forces in the North of Italy.

Finally, the current law has been described, together with the expected amendments, with comments on their consequences, in the hope that public opinion as well as lawmakers will show greater interest in these matters, and consequently develop better environmental protection.

\section{REFERENCES}

[1] Paoletti, A., Braga, G., Colombo, A., Croci, S., Peduzzi, G.B. \& Savazzi, G., La gestione dei sedimenti alluvionali dell'alveo inciso del fiume Po. L'Acqua, n. 2, 2007 (in Italian).

[2] Adamoli, L., Relazione geologica, geomorfologica, idrogeologica e sismica. Appalto concorso per la salvaguardia idraulico-ambientale del fiume Vomano. Progetto esecutivo, Teramo, July 2004 (in Italian).

[3] Mereu, U., Il fiume tradito: l'escavazione abusiva in alveo. Silvae, II, n. 7, Corpo Forestale dello Stato, Roma, 2007 (in Italian).

[4] Legambiente, Il punto sulle cave in Italia. Report Legambiente, 2008 (in Italian).

[5] Chang, H.H., Fluvial Processes in River Engineering. John Wiley \& Sons Pub.: New York, 1988.

[6] Kondolf, G.M., Hungry water: effects of dams and gravel mining on river channels. Environmental Management, 21(4), pp. 533-551, 1997. doi:10.1007/s002679900048 
[7] Bull,W.D. \& Scott, K.M., Impact of mining gravel from urban streambeds in the southwestern United States. Geology, 4, pp. 171-174, 1974. doi:10.1130/0091-7613(1974)2<171a: IOMGFU>2.0.CO;2

[8] Kondolf, G.M., Geomorphic and environmental effects of instream gravel mining. Landscape Urban Plan, 28, pp. 225-243, 1994. doi:10.1016/0169-2046(94)90010-8

[9] Carson, M.A. \& Kirby, M.J., Hillslope form and process. Cambridge University Press: Cambridge, 1972.

[10] Brugioni, M. \& Menduni, G., Alcune osservazioni sulla stabilità delle sponde e sull'idraulica degli alvei a sezione composite nei corsi d'acqua naturali. Proceedings of "La difesa idraulica del territorio", eds U. Maione, \& A. Brath, 7-11 October 1996 (in Italian).

[11] Ferraiolo, F., Opere idrauliche: protezioni di corsi d'acqua e litorali. Proceedings of "La progettazione della difesa idraulica", eds U. Maione, A. Brath \& P. Mignosa, 2-6 October 2000 (in Italian).

[12] Ballio, F., Bianchi, A., Franzetti, S., De Falco, F. \& Mancini, M., Vulnerabilità idraulica di ponti fluviali. Proceedings of XXVI Convegno Nazionale di Idraulica e Costruzioni idrauliche, Catania, 9-12 September 1998 (in Italian).

[13] Brandimarte, L., Brath, A. \& Montanari, A., Modelli interpretativi dei fenomeni di erosione in alveo in corrispondenza di attraversamenti fluviali. Proceedings of "La progettazione di opere idrauliche in zona montana”, eds U. Maione, A. Brath \& P. Mignosa, 7-11 October 2002 (in Italian).

[14] Chang, H.H., Fluvial Processes in River Engineering. John Wiley \& Sons Pub.: New York, 1988.

[15] Brown, A.V., Lyttle, M.M. \& Brown, K.B., Impacts of gravel mining on gravel bed streams. Trans Am Fish Soc, 127, pp. 979-994, 1998. doi:10.1577/1548-8659(1998)127<0979: IOGMOG $>2.0 . \mathrm{CO} ; 2$

[16] Pauley, G.B., Thomas, G.L., Marino, D.A. \& Weigand, D.C., Evaluation of the effects of gravel bar scalping on juvenile salmonids in the Puyallup River drainage. University of Washington Cooperative Fishery Research Unit Report. University of Washington, Seattle, 1989.

[17] Lemos, M.M.G., Subsidies to rehabilitation of sand extraction open water-ponds in the Paraiba do Sul River floodplain, Sao Paulo. MSc Thesis, Sao Paulo University, 1999.

[18] Lemos, M.M.G., Menezes, G.V., Eysink, G.G.J., Beyruth, Z., Costa, M.P. \& Martins, M.C., Environmental quality of sand extraction open water ponds in Jacarei, Sao Paulo: subsidies to the control and rehabilitation. CETESB Technical Report, Sao Paulo, 1997.

[19] Rovira A., Batalla, R.J. \& Sala, M., Response of a river sediment budget after historical gravel mining (the lower Tordera, NE Spain). River Res. Applic. 21, pp. 829-847, 2005. doi: $10.1002 /$ rra. 885 